\title{
Indigenes and Settlers Conflict in Nigeria: A Negation to National Integration and Nation Building
}

\author{
Dr. Ejikeme Jombo Nwagwu
}

Lecturer, Department of Political Science, University of Nigeria, Nsukka Email: ejikeme.nwagwu@unn.edu.ng

\section{Doi:10.5901/mjss.2016.v7n4p}

\section{Abstract}

\begin{abstract}
The issue of indigenes and settlers rivalry has remained for many decades the principal source of intractable intra/intercommunal violent conflicts in Nigeria. As a result of the intransigent trend, many communities have been destroyed, cases of colossal loss of lives and properties have been recorded, and millions of displaced people have been vulnerable to abuses, hunger, infections, epidemics and other related consequences. Women and children are the major victims of this inconsequential aberration to rule of law and good governance. These problems of communal and ethnic rivalries seem to have overwhelmed governments as the crises are being managed rather than being resolved. The objective of this article is to investigate the root causes of the intra/inter-communal conflicts which centred on indigenes and settlers rivalries and its effect on national integration and nation building, which structural mechanism guarantees harmonious co-existence of all tribes irrespective of location, religion, ethnicity, or political affiliation. The article will also investigate why governments at all levels have failed to proffer enduring solution to this scourge. Qualitative method was adopted for documentary evidence, as it was considered the appropriate method for data generation; and content analysis was applied as method of data analysis. The study revealed that lopsided redistribution of society benefits and the unhealthy struggle for scarce economic resources, cultural heritage syndrome and distrust are the main causes of indigenous claim and settlers discrimination. There is need for Nigerian people to live together in harmony and harness the abundant resources for the development of the country.
\end{abstract}

Keywords: Indigenes/Settlers, Ethnic Conflicts, National Integration, Nation Building

\section{Introduction}

The emergence of indigenes and settlers unhealthy rivalries in most parts of Nigeria has remained for many decades one of the major sources of intractable inter-ethnic crisis bedeviling the sovereign nation. The indigene and settler phenomenon is a cancerous disease in the body polity of any nation as cancer is to the human body system. If the problem is not detected early enough and treated effectively to cure the ailment, if allowed to spread to other body components, it would either pose insurmountable health challenges or destroy the entire system. Its effect is therefore disastrous to national integration and nation building. In human history, issues bordering on communal conflicts, interethnic crisis, are common phenomena as conflict is a reality of social relations at the individual, group, organizational, community and societal levels. As late as pre-colonial period, and during colonial era, many African ancient kingdoms experienced inter-kingdom dynastic feuds or inter-community conflicts within kingdoms.

In modern society, the intractable conflicts emerging from the saga of indigene/settler in various parts of Nigeria stem from the conception, definition and perception of the character of who is an indigene and who is a settler; which defines what rights indigenes have over non-indigenes. The value of "indigene status" arose from the emergence of unhealthy ethnic-based divergent interests, desires, and aspirations in the crude competition for scarce resources to meet the conflicting demands of human relations in a defined society. As a result of the intransigent trend, many communities have been destroyed, cases of colossal loss of lives and properties have been recorded, and millions of displaced people have been vulnerable to abuse (e.g. rape, hunger, infections, epidemics) and other related consequences. Women and children are the major victims/casualties of the lawlessness. Experience of Nigeria in ethno-religious crisis, intra-communal conflicts, and inter-community feuds, which borders on indigene and settler issues abound. For instance, Gyang Dantong, a Senator representing Plateau North Senatorial District, and Gyang Filani, a member representing Barikin Ladi constituency in Plateau State House of Assembly were alleged to have been brutally murdered in cold blood by Fulani attackers. In 2014, the Governor of Benue State, Gabriel Suswan narrowly escaped death when the Fulani herdsmen attacked his convoy during an inspection tour of the crisis area in Benue State. Such other cases as the Zangon-Kataf crisis in Kaduna State (1992-2001) between the Atyaps (natives) and Hausa/Fulani tribes; the Tiv-Jukun- 
Wukari conflict in Taraba State (1999-2001); the Aguleri and Umuleri conflict in Anambra State (which recurred in 30 years interval - 1936, 1966, and 1996); the Itsekiri-Urhobo-Warri inter-community conflict in Delta State (1999-2000); the Ezza-Ezillo communal conflict in Ebonyi State; the Ife-Modakeke communal conflict in Oyo State (from pre-colonial era till date); the Hausa/Fulani and Berom/Anaguta/Afizere crisis in Jos, Plateau State (2009 - date); the Niger Delta conflicts (which primarily borders on economic deprivation, environmental degradation, political marginalization, governmentdriven impoverishment and underdevelopment of the region); the scourge of faceless Boko Haram sect with no ideological base; the Tiv and Fulani herdsmen crisis in Makurdi, Benue State (2014); and a litany of other recorded and unrecorded incidents of indigenes and settlers conflicts in families, villages, and communities in Nigeria. Nigeria is a heterogeneously constituted society where ethnic-based conflicts flourish, and distrust amongst tribes is very high; where most natives are ill-informed, issues are based on ethnic sentiments to foster the struggle for resource control, and each ethnic-group 'fight' to have undue advantage to federal or state benefits. The indigene status provides 'indigenes' the identity, recognition, affinity and meaning for individual members of the group acting individually or collectively to defend group interests. The non-indigenes, on the other hand, wage war against host communities to defend themselves. (Otite and Albert, 1999; Osaghae and Suberu, 2005; Best, 2006).

These perennial problems of inter-communal and ethno-religious rivalries seem to have defied all known conflict resolution strategies. The insurgence, from all indications, seem to have gradually overwhelmed government coercive apparatuses as the crises are being managed rather than being resolved. The objective of this study is to investigate the root causes of the intra/inter-communal conflicts which centred on indigenes and settlers rivalries; and its effect and meaning on national integration and nation building, which mechanism was structured with the intent to guarantee safety and harmonious co-existence of all ethnic tribes irrespective of location, religion, ethnicity, or political affiliation. The article also investigated why governments' efforts at all levels have failed to proffer enduring solution to this scourge that is ravaging societies.

\section{Concept of Indigenous Peoples}

Jones (2012) defined the term 'indigenous peoples' as referring to the original or native inhabitants of areas that have been colonized by Europeans, especially in Africa, Asia, America and Australasia. The category of indigenous populations was adopted for the first time in international law by the International Labour Organization in ILO Convention no. 107 of 1957 concerning the protection and integration of indigenous and tribal populations in independent countries.

The concept "indigenous" is derived from the two Ancient Greek words "indo", meaning inside/within, and "genous", meaning birth/born and also race. Etymology meaning "native" or "born within". Its literal meaning in English Language is any given people, ethnic group or community may be described as indigenous in reference to some particular region or location that they perceive as their traditional tribal land claim. Other concepts used to underline indigenous populations are aboriginal, native, original, first, and hereditary owners in indigenous law. Besides, the use of the term "peoples" in association with the term "indigenous" is derived from the $1^{\text {th }}$ century anthropological and ethnographic disciplines in Merriam-Webster (http://en.wikipedia.org/wiki/Indigenous-peoples).

There are varying definitions of the concept "indigenous peoples" by different scholars of divergent perspectives and organizations of international or national outlook. The international or national legislation definition of the term "as peoples having a set of specific rights based on their historical ties to a particular territory, and their cultural or historical distinctiveness from other populations that are often politically dominant". The legislation is based on the conclusion that certain indigenous people are vulnerable to exploitation, marginalization and oppression by nation states formed from the colonizing populations, or by politically dominant different ethnic groups. The legal definitions of indigenousness have changed over time to reflect the changing perceptions of the people within the framework of conceptualization "indigenousness" as it connotes in Africa from the advent of the colonial rule until decolonization, the concept was used to refer to all non-European natives on territories conquered and colonized by European powers; under the early years of the post-colonial reign, indigenousness was popularized as a concept referring to non-Europeans in countries where peoples mainly descending from European settlers remained dominant; and the indigenous rights movement was internationalized to cover other marginalized groups, in continents like Africa, Asia, Europe and the Pacific (http://en.wikipedia.org/wiki/Indigenous-peoples). An inference is drawn from the plight of indigenous peoples of Australia in their collective efforts to defend their lands, languages, and cultures as aboriginal Australians as thus:

The government of Australia has a very poor record when it comes to treatment of its aboriginal citizens. Indigenous Australians were dispossessed of their land, despised for their culture, and marginalized, abused, and murdered. Perhaps most notorious of all the Australian policies were those that led to what has become known as the "Stolen 
Generations". Under several federal and state programmes that continued into the 1970s, the government forcibly removed aboriginal children from their families and sent them to white families and church-run institutions for cultural reprogramming. A recent national report on the policies found that there was not a single indigenous family that did not have at least one child taken away. Despite the deliberate genocidal nature of these programmes, the government for many years refused to apologize for them. That same hostile attitude toward aboriginal peoples was reflected in the Australian government's long and vigorous opposition to the United Nations Declaration on the Rights of Indigenous Peoples (http//www.culturalsurvival.org/Australia?gclid).

A study showed that the indigenous people of Australia, on the average, live 17 years less than non-indigenous people, and every measure of social and physical welfare from infant mortality to nutrition, health, housing, education, and employment is significantly lower for aboriginal Australians than for non-indigenous Australians. Similarly, all of the negative markers for disenfranchised populations - imprisonment, domestic violence, alcoholism - are much higher for aboriginal peoples. For example, an aboriginal man is 13 times as likely to be in jail as against a non-indigenous Australian, and an indigenous teenager is 28 times more likely to be in jail. Although a change in administration has led to an unreserved national apology from the new government for the "Stolen Generations". As an annual event, the country as a whole celebrates "Sorry Day" to express remorse for the dark days. The new government has also reversed the country's opposition to the United Nations Declaration on the Rights of Indigenous Peoples. These favourable developments notwithstanding, the problems currently facing indigenous Australians are similar to those of indigenous peoples around the world as the ugly experiences have left indelible scars in the lives of common indigenous peoples of Australia, Shetland (Jones, 2012; http//www.culturalsurvival.org/Australia?gclid).

Indigenous peoples confront a diverse range of concerns associated with their status and interaction with other cultural groups, as well as changes in their inhabited environment. Some challenges are specific to particular groups; however, other challenges are commonly experienced. These issues include cultural and linguistic preservation, land rights, ownership and exploitation of natural resources, political determination and autonomy, environmental degradation and incursion, poverty, health and discrimination. A disturbing phenomenon is that the interaction between indigenous and non-indigenous societies throughout history of mankind has been complex, ranging from outright conflict and subjugation to some degree of mutual benefit and cultural transfer. A particular aspect of anthropological study involves investigation into the ramifications of what is termed "first contact", the study of what occurs when two cultures first encounter one another. The situation can be further perplexed when there is a complicated or contested history of migration and population of a given region, which can give rise to disputes about primacy, identity and ownership of the land and resources. Example from the Northern Isles of Scotland is the Shetland and Orkney Udal Law group (SOUL) which includes on its website links to legal decisions in favour of indigenous rights in Canada and Australia. SOUL argues in favour of greater autonomy for Shetland and for Shetland's resources to be used for the maximum benefits of Shetland people. (Jones, 2012; http://en.wikipedia.org/wiki/lndigenous_peoples).

Political marginalization and socio-economic deprivation are some of the major issues indigenous peoples fight against to liberate their freedom. In effort to maintain non-dominant sectors of society, they are determined to preserve, develop, and transmit to future generations their ancestral territories, and their ethnic identity as the basis of their continued existence as peoples. Although there is no single universally accepted definition of the term "indigenous people", the four most often invoked elements in its discourse are a priority in time; the voluntary perpetuation of cultural distinctiveness; an experience of subjugation, marginalization and dispossession; and self identification. Perhaps, this historical continuity may consist of the continuation, for an extended period reaching into the present occupation of ancestral lands, or at least of part of them; common ancestry with the original occupants of these lands; culture in specific or general manifestations (with such indicators like religion, dress, living under a recognized tribal system, membership of an indigenous community, beliefs, means of livelihood, lifestyle, etc.); native language may be applied as the only official medium of communication (as mother-tongue), or may be adopted as the habitual means of communication at home or in the family; or preferred as the main habitual, general or normal language; and residence in certain parts of the country or in certain regions of the world (Jones, 2012; http://en.wikipedia.org/wiki/Indigenous_peoples).

\section{Methodology}

Ex-post facto research design was applied in carrying out the study because the events under study had already taken place before the study took place. Qualitative method of data collection was used to glean data from documentary evidence of secondary sources. The method was considered appropriate in considering large population of the study area and the vast scope of the research. Qualitative descriptive method of analysis was adopted in analyzing the data generated from documentary evidence. The study was guided by the following research questions: (1) Does indigene and 
settler conflicts undermine national integration in Nigeria? (2) How does indigene and settler conflicts defy all conflict resolution strategies in Nigeria? The hypotheses are: (1) Indigene and settler conflicts undermine national integration in Nigeria. (2) Indigene and settler conflicts defy all conflict resolution strategies in Nigeria.

\section{Right to Freedom from Discrimination in Nigeria}

Section 42, subsections (1)(a)-(b) and (2) of the 1999 Constitution of the Federal Republic of Nigeria (as amended), under this subheading, provides that a citizen of Nigeria of a particular community, ethnic group, place of origin, sex, religion or political opinion shall not, by reason only that he is such a person -

(a) be subjected either expressly by, or in the practical application of, any law in force in Nigeria or any executive or administrative action of the government, to disabilities or restrictions to which citizen of Nigeria of other communities, ethnic groups, places of origin, sex, religion or political opinions are not made subject; or (b) be accorded either expressly by, or in the practical application of, any law in force in Nigeria or any such executive or administrative action, any privilege or advantage that is not accorded to citizen Nigeria of other communities, ethnic groups, places of origin, sex, religion or political opinions (FRN, 1999).

Subsection (2) stipulates that "no citizen of Nigeria shall be subjected to any disability or deprivation merely by reason of the circumstances of his birth".

The Constitution is sufficiently explicit in determining who is a Nigerian and who is not, as it stated that any person born in Nigeria before $1^{\text {st }}$ October, 1960 , either of whose parents or any of whose grandparents belongs or belonged to a community indigenous to Nigeria. Indigenous peoples have special attachment to and use of their traditional land whereby ancestral land and territory has a fundamental importance for their collective physical and cultural survival as peoples; on an experience of subjugation, marginalization, dispossession, exclusion or discrimination because these peoples have different cultures, ways of life or modes of production than the national hegemonic and dominant model. When an African indigene claims that he is "son of the soil", he simply means that his origin could be traced to a particular indigenous family of a specific clan which belongs to a particular ethnic group with ancestral history. The historical and ancient connection with lands and territories is of crucial importance in determining the indigenous peoples status. The indigenous peoples have the right to determine their own identity or membership in accordance with their customs and traditions. This does not impair the right of indigenous individuals to obtain citizenship of the States where they live. Indigenous peoples have the right to determine the structures and to select the membership of their institutions in accordance with their own procedures. http://indigenouspeoples.nl/indigenous-peoples/definition-indigenous; Jones, 2012).

There are cultural procedures through which the indigenes assimilate and acculturate the settlers into the host communities for harmonious co-existence. Autonomous rural communities are ruled by their respective traditional rulers. The traditional rulers, within their jurisdictional confinement, rule over their subjects, clans or tribes that are naturally tied to the land. The indigenes are tied to local belief system, culture, mores and politics. Even the dead is buried in his own portion of the land, not elsewhere. Any government that tries to coercively distort this ancient order will risk its legitimacy. Conflict often erupts if settlers refused to be assimilated and acculturated by the original inhabitants of a specific area, by making untenable demands on host communities bordering on political appointments, economic issues between native farmers and settlers with a view to dominating the indigenes, or infringing on their rights as a people. The aborigines will naturally resist the incursion of settlers with deliberate attempt to ward-off the elements perceived as "invaders" in their communities (Campbell, 2012; Adetutu, 2012).

Indigenes have significant advantage over settlers on socio-political and economic issues, and it is the local government authority and the state government's responsibility to identify who is an indigene within their legal jurisdictions respectively. The central government has no role to play in this civic responsibility, hence the central government's constraint in meddling into indigenes and settlers conflicts. This also argues why local and state governments have no faith or are unwilling to accept the outcome (reports and recommendations) of the various committees set-up by the central government to investigate indigene and settlers crisis in any part of the country. The settlers themselves have no trust nor confidence in the judicial panels of inquiry constituted by various state governments to look into the crisis of indigene and settlers; rather they prefer the central government interventions on the issues patterning to indigenous status.

\section{Incidence of Indigenes and Settlers Conflicts in Nigeria}


Ehusani (2005:1) observed that one of the lingering contradictions of the Nigerian state is the phenomenon of natives and settlers among the same people who lay equal claim to Nigerian citizenship, and who have been engaged in cultural, religious, economic and political exchanges for over 100 years. Whereas the so-called settlers are part of the society in every respect, worshipping, socializing and trading, paying taxes, and marrying the so-called indigenes, but when it relates to sharing of resources, including ownership of land, the indigene/settler sentiments is whipped-up and the socalled settlers often suffer gross injustice of discrimination and persecution. Two incidence of indigenes and settlers conflicts are discussed hereunder:

\subsection{Zangon-Kataf Crisis}

Zangon-Kataf is located in southern part of Kaduna State. The population is largely Christians, with Hausa/Fulani in the minority. The crisis reared its ugly head in 1992 and stretched to 2010. The central issues on ethno-religious conflicts are the deprivation of access to basic economic resources, unequal opportunities, unresolved fear of domination of one sect by the other, socio-political marginalization, perceived ethnic chauvinism and unhealthy religious and cultural rivalries amongst communities that ignite avoidable scuffle. The Atyaps claim ownership of Zangon-Kataf since 1850s; while Hausa/Fulani claim traditional authority of Zaria Emirate over Zangon-Kataf. The imposition of aristocratic rule from Zaria Emirate on Zangon-Kataf enthrones political domination over the aborigines. Religion, culture, and poverty are some of the factors precipitating violent conflicts in Christian/Muslim communities.

The 1992 Zangon-Kataf violence centred on mere suspicion of Muslims of an intent of the Local Government Chairman (a Christian) to relocate the major market in the urban area "in order to disadvantage" the Hausa/Fulani living in the area. A misconstruction of the government intention to decongest the busy urban centre and relocate the main market in the commercial city to a neutral ground in the outskirts of the local government headquarters was due to prevalent antagonistic relationship existing between Muslims and Christians in the area. The decision to relocate the market was perceived by Hausa/Fulani community as a government-driven policy to dislodge them from their firm grip of economic activities and dispossess them of their political clout in the area. Hausa/Fulani dominate the indigenes in all spheres of human endeavour - socio-culturally, politically, and economically and the situation has been exacerbated by the Muslim and Christian divide. The situation became so precarious as the colonial authority created lines of socio-religious cleavages by establishing Native Authority School and Mission Schools for Muslims and Christians respectively. The Native Authority Schools were restricted to the children of the Emirate Council, which was discriminatory in practice. It was alleged that the purpose was to produce a continuous pool of graduates for tax collection on Atyaps. On the other hand, the missionaries created mission schools in 1940s; and Atyaps who felt oppressed, subjugated, and marginalized by Hausa/Fulani hegemony, embraced Christianity as an alternative to their plight. The introduction of two conflicting and contradicting court system and two different school systems in a volatile terrain where religious intolerance is very high, heightened the level of social awareness and political consciousness of the native Atyaps. As a result, Atyaps women and youths became more resentful of the superiority complex of the Hausa/Fulani, and their claimed supremacy in socioeconomic enterprises deepened ethno-religious differences (Adetula and Dung, 2006; Egwu, Salihu and Kure, 2003; Akpuru-Aja, 2007). The conflict recorded colossal waste of lives and property. The state and federal governments were accused of complicity in their doubtful efforts to intervene.

\subsection{Hausa/Fulani and Berom/Anaguta/Afizere Crisis in Jos}

The Berom people are the indigenous ethnic group of Jos, Plateau State in Nigeria. Within the State, they concentrated mostly in the local government areas of Jos South, Jos North, Barkin Ladi (Gwol), and Riyom. Berom has a population of $1,083,000$ out of which $96 \%$ are Christians, according to 2006 census. (http://en.wikipedia.org/wiki/Berom_people). Ironically, the Jos crisis is multicultural, multifarious, and multilateral in nature and scope. It has many ethnic group contenders for Indigeneship of the land "Jos", particularly the Jos North Local Government Area. Berom tribe is one of the contenders, who claims that Jos is their ancestral inheritance. They claim that Berom settled and secured Jos along with Anaguta people prior to the adventure of the colonialists who made Jos the administrative centre of their government by conquest. According to them, Hausa/Fulani people were brought into Jos by British colonial masters as cheap labour in the Tin mining activities, which was the main commercial activity in the area then. (Sampson, n.d).

The Anaguta, people in Jos, corroborates with Berom and Afizere ethnic groups that Hausa/Fulani groups are settlers in the land. Therefore, they have no portion in Jos to claim as theirs. Anaguta community agreed that the Hausa/Fulani people have been instrumental to the development of Jos, but this does not translate to a right of ownership of Jos. They consider themselves as the true indigenes of Jos not other claimers. Anaguta claims that its tribe was the 
first to arrive the place called "Jos". This ethnic group dismissed the idea of Hausa chiefs being rulers of the area, and considered their claim of having ruled Jos from time immemorial as baseless assertion because the immigrants migrated to Jos not by conquest before, during, or after colonialism (Sampson, n.d).

The Afizere, another ethnic group in Jos, corroborated Berom's claim that Hausa/Fulani people in Jos are settlers and non-indigenes of Jos, who do not appreciate and reciprocate the hospitality showered on them by their host communities. The Afizere considers Hausa/Fulani as a group that has no right to claim the traditional authority and land in Jos. They debunked claims of Anaguta and Berom ethnic groups as the owners of Jos. Afizere claims that Jos belongs to them and there is ample evidence to prove their stance. According to Afizere, the boundary between them and Berom was located at the Bukuru Low Cost Bridge; but Colonial administrators joined Afizere land to Bauchi Province and Berom acquired most parts of Jos without resistance (http://www.nairaland.com/998903/perspectives-causes-conflictsjos).

Hausa/Fulani groups claim that they established Jos from nothing and nurtured it into what it is today without the help of the so-called indigenous ethnic groups. The central issue of their argument is that Jos was established around the nineteenth century out of a virgin land with none of the indigenous groups near the vicinity they now claim to be theirs respectively. Turakin Jos, Alhaji Inuwa Ali, a paramount Hausa/Fulani leader in Jos, reaffirmed in 2002, in a speech he delivered at the Presidential Retreat on Peace and Conflict Resolution at the National Institute for Policy and Strategic Studies, Kuru, Jos, 23-26 January, that Jos is a Hausa settlement and this had been confirmed by Mr Ames, a colonial administrator, who gave the population of Jos town in 1950 as 10,207, out of which 10,000 people were Hausa/Fulani origin (http://www.nairaland.com/998903/perspectives-causes-conflicts-jos).

\section{Causes of Indigenes and Settlers Conflicts}

The underlying cause of conflicts in Zango/Kataf was the imposition of aristocratic rule of Muslims from the Zaria Emirate upon the native Atyaps, which enthroned political, socio-economic domination of the area in favour of Hausa/Fulani; application of sharia laws against the non-Muslim Atyaps which unwittingly sharpened the "two-edged-sword" for assault. The imposition facilitated superior external forces to annex and control Atyaps land which belonged to Kataf peasants. Similarly, the local government authority's plan to relocate the local market from the main busy town area to an outskirts of the local government headquarters provoked the Hausa/Fulani tribe and created source of conflict. Also, religious and cultural intolerance and forceful incursion of Fulani herdsmen into farming areas of some autonomous communities are elements of the major sources of bloody clashes between Hausa/Fulani and the host communities all over the country. Hausa/Fulani herdsmen are unlawfully ubiquitous to graze their cattle around communities' farming zones. Grazing of cattle around farmlands is one of the major sources of bloody conflicts between the Hausa/Fulani herdsmen and other ethnic groups in Nigeria. The media war, the inflammatory and provocative insinuations, unguarded and inciting utterances raging uncontrollably across the two hostile ethnic groups in a horizontal level was an ignitive factor to the bottled conflict; the written threat by Kataf village heads with the community leaders' 'blessings', in which they indicated their intention to repossess Kataf land allegedly appropriated by the Emir of Zaria and assigned to Hausa tribe in 1920; the backup action of uprooting the crops on Hausa farmland by the Kataf indigenous youths to actualize the land restitution were eloquent indicators of impending conflict between the two tribes. A subsequent retaliatory attack on Kataf and their farmland by the Hausa tribe; the alleged annihilation and dispossession of Hausa Muslims by "infidels" in Zangon-Kataf were sufficiently enough early warning signals for the impending conflict of 1992; but these indicators were ignored by relevant authorities until the crises bursted and escalated beyond Zangon-Kataf region with its toll of casualties and destruction of properties (Kpuru-Aja, 2007). As observed by Akunteye, Wuye and Ashafa (cited in AkpuruAja, 2007):

\footnotetext{
when the riot broke out in 1992, it took a religious dimension in Kaduna city and its environs. The Muslims in the city took it to mean the killing of the Muslims while their Christian counterparts took it to mean the killing of the Christians by the Muslims. It was reported that some Hausa corpses were brought to the city from the site of the incident and this action incited the Muslims in the city, especially in Tudun Wada area where no single Christian was spared. On the other hand, in Sabon Tasha, the Christians made sure that no single Muslim was spared too. Lives were lost and properties worth millions were also destroyed.
}

Cultural intolerance of the Atyaps for dieting on forbidden pork and consumption of alcohol, and the Atyaps' women and youths disposition of somewhat more resentful of the superiority complex of the Hausa/Fulani; the Hausa/Fulani claims of authority, entrepreneurship, military supremacy, and hegemony in political and socio-economic enterprises, deepened ethno-religious cleavages; and nursed possible out-burst of bottled grievances bordering on political and 
economic marginalization, suppression and subjugation; exploitation and enslavement of the original indigenes by settlers. The bloody conflict would have been avoided, but for the insensitivity and weak regime responses by the successive state and federal governments, the early warning indicators were trivialized or bluntly ignored due to partisan interests and religious inclination in the heinous feud.

The complex and precarious situation in Jos, Plateau State was exacerbated by multiple and conflicting claims Berom/Anaguta/Afizere against Hausa/Fulani in the region. The claims and counter claims of Indigeneship in Jos by all stakeholders, the heating up of the polity by the federal government's nepotistic appointments in Jos in favour of the Hausa/Fulani settlers, infuriated disadvantaged ethnic groups and subsequently caused disharmony, havoc and distress. Apart from indigene/settler disharmonious syndrome, religious and cultural intolerance, political marginalization and economic deprivation are some of the major factors contributing to ethno-religious conflicts in Nigeria. Considering the degree of emotions and intensity of the conflict by the atrocities that are being carried out by the violent extremists of both Moslems and Christians in the feuds, which gives the impetus for the major political issues that are being vigorously and violently contested along the lines of the complex ethnic nationalities, religious, indigene/settler, and regional divide in the country. The existence and legitimacy of the state are the fundamental matter at issue that generates fiercest contestation among competing ethnic groups, with zero-sum intent, to control the state power, resource allocation and citizenship status. Every public issue is ethnicized till it degenerate to a serious ethno-religious intractable feud (Smyth and Robinson, 2001). Falola and Heaton (2008) succinctly noted that "since ethnic patronage has remained a key element of Nigerian politics, individuals depend on ethnicity to mobilize and create power relations. When the competition for values (state power) and resources intensifies between and within ethnic groups, individuals with access to the seat of government and state law enforcement apparatuses utilize such mechanisms to exploit ethnic networks, whip-up movements or sentiments to gain support and influence".

\section{Dynamics of Indigenes and Settlers Conflicts in Nigeria}

The volatility of any conflict actually depends on the pattern of regime responses. In other words, the institutional mechanisms of government play crucial roles in conflict avoidance, conflict prevention and tension reduction as maintenance of peace and orderliness is essential to ensuring security of lives and properties, and it is critical to the principal responsibility of the government. This necessary ingredient was highlighted in Section 14(2)(b) of the 1999 Constitution of the Federation to the effect that "the security and welfare of the people shall be the primary purpose of government". In situations where the institutions of government remain quite unconcerned, or indifferent or non-challant, the possibility is the graduation of conflict signals to full-scale explosive conflict scenario. In the alternative where government or any traditional institution is sensitive and responsibly responsive, the possibility of a conflict scenario turning into explosive crisis is remote. As a corollary, the impartiality of the regime response is a positive variant of conflict management (Akpuru-Aja, 2007:94).

The partisan disposition of the successive regimes and their deceifful stance on sensitive and explosive issues bordering on state security involving Hausa/Fulani and other ethnic groups in Nigeria cast doubts in public minds on the sincerity of the government in maintaining egalitarian state where preference is not given to any particular ethnic group or religious sect against others. The ethnic conflicts in many parts of Nigeria are being fanned by actions and inactions of government, particularly with respect to lopsided constitution of panels of inquiry with ethnic bias and inaction of government on reports and recommendations of these panels, sustains the conflicts. Albert (2004) predicts that the IfeModakeke crisis will still claim more lives and further destruction of property unless the pattern of regime responses changed pro-actively. He noted that the persistence of the Ife-Modakeke crisis is caused more by the weak responses of the successive regimes rather than the communities themselves. The conflict resolution of the Ife-Modakeke crisis has been made much more difficult by either apathy, or partisan responses of the successive administrations. The peace responses by administration stretches through the pre-colonial traditional peace approach, the colonial interactive peace approach, and the post-colonial partisan peace approach of successive governments without one yielding any positive enduring result to end the conflicts (Akpuru-Aja, 2007; Adetutu, 2012). The seeming support of the government on the Hausa/Fulani claim of traditional authority of the Zaria Emirate, superiority in power, and entrepreneurship over the inhabitants and residents of the Zangon Kataf; imposition and extortion of taxes from the Atyaps indigenes by the Hausa ethnic group; the condemnation of retired military officer, Zamani Lekwot (an Atyap) to death by the panel of inquiry headed by a Hausa/Fulani extraction as aftermath of the crisis; and the partisan disposition of the State Governor over the crisis were not meant to resolve the conflict, rather to exacerbate the ethno-religious conflicts in the area for cheap popularity.

The control of the central government for decades by the Hausa/Fulani ethnic group gives the tribe the leverage to 
compel other tribes to their whims and caprices since independence, as federal government is evidently in support of the Hausa/Fulani ethnic extractions wherever there is conflict between the tribe and other ethnic groups. Most often, the central government deliberately creates confusion and acrimony in communities housing Hausa/Fulani and against the host communities (indigenes) by allotting federal political appointment positions (the constitutional rights of the indigenes based on the principle of federal character or quota system) to settlers instead of rightful indigenes. For instance, the military governor's appointment of Aminu Mato as Caretaker Chairman of Jos North Local Government Area in 1994; the appointment of Ado Ibrahim as Jos North Local Government Education Secretary in 1996; the appointment of Muktar Mohammed as Jos North Local Government Area NAPEP Coordinator in 2001; the contest for the position of Director General of the National Institute for Policy and Strategic Studies, Kuru in Plateau State between indigenes of Plateau State and Federal Government in favour of Hausa/Fulani appointee, and the insistence of then Governor of the State, Joshua Dariye that it was their birth right to produce an indigene as the head of any federal establishment in the state, helped to aggravate the crisis. The former President Umaru Musa Yar'Adua's regime also selected a Hausa/Fulani resident in Plateau State as a ministerial nominee on the slot of Plateau State indigenes. This was a violation of Section 14(3) of the 1999 Constitution of the Federation which stipulates that:

the composition of the Government of the Federation or any of its agencies and the conduct of its affairs shall be carried out in such a manner as to reflect the federal character of Nigeria and the need to promote national unity, and also to command national loyalty, thereby ensuring that there shall be no predominance of persons from a few States or from a few ethnic or other sectional groups in that Government or in any of its agencies (FRN, 1999).

The Plateau State Government, in spite of all odds, maintained its stance to shield their indigenes from the provocative and incisive actions and inactions of central government to incite the settlers against their host state indigenes. The indigene/settler crisis obviously serves as a political tool to whip-up and mobilize ethnic sentiments to sustain instability (cold war) in these conflict ridden zones and remain politically relevant as powerful representatives of the people at the centre. The refusal of the Chief Justice of Nigeria (CJN), Justice Maryam Aloma Mukhtar, to swear-in Justice Ifeoma Jombo-Ofo, the Anambra State-born High Court Judge married to an Abia man, as Justice of the Court of Appeal because a petition alleged that Justice Ifeoma Jombo-Ofo was not an indigene of Abia State by birth. Marriage and National Integrative policy have automatically transferred Indigeneship to Justice Jombo-Ofo as a bona-fide indigene of Abia State. The Federal Government could not bulge as this is one of its delicacies "fanning indigene/settler feuds to heat the polity". It argued that swearing-in Justice Jombo-Ofo would contravene the federal character principle as enshrined in the 1999 Constitution. This argument on federal character was considered illogical when several nonindigenes (Hausa/Fulani extractions) in Plateau State were being nominated or appointed to fill the indigenes' quota in Plateau State (http://agora.nigeriagovernance.org/2012/11/cjn-refuses-to-swear-in-appeal-court-justice/).

The relative dominance of the Hausa/Fulani ethnic group in political offices at the central government accounts for why federal government, in its attempt to jeopardize the efforts of the states' governments, constituted parallel panels of inquiry in Jos crisis and Zangon-Kataf conflict to reflect ethnic preference and the use of public resources to prosecute ethno-religious agenda, supports the fears of non-Hausa/Fulani tribes of federal government's partisan in the conflicts. The apparent weakness of the Plateau State Government to implement the reports and recommendations of the stateconstituted panels of inquiry on the crisis was due to strategic occupation of key positions at the central government by the Hausa/Fulani extractions. For instance, the promotion of the former Commissioner of Police in the state during the crisis, Alhaji M.D. Abubakar, to Inspector General of Police, an officer who was alleged to have been indicted of complicity in the whole affairs; the unwillingness or apparent failure of federal government to prevent massive killings, maiming, and affliction of physical injuries to innocent and harmless citizens by lawless individuals or groups of ethnic bias in the event of ethno-religious conflicts; inability to protect citizens' property from unlawful destruction at the least ignition of ethno-religious crisis; and very low (close to zero) record of prosecution of culprits are indices of bias against the central government stance (Ostien, 2009; Adetutu, 2012).

Osaghae and Suberu (2005) opined that maintenance of peace and security, which is the major indicator and hallmark of good and democratic governance, is critical to the responsibility of the state. The role of central government as both the regulator of the fierce competition amongst the diverse ethnic groups and the guarantor of peace and security is paramount in its functions to harmonize the activities of all stakeholders in the Nigeria project. The inability or low capacity of government to protect its citizens from wanton killings and destruction of properties by the religious extremists subjects its constitutional authority and legitimacy to questions. As succinctly noted by Ibrahim (1999):

the legitimacy of the modern state is linked to its capacity to present itself as a provider of public goods and, more importantly, a neutral arbiter that guarantees the security of all sections of the society. When the state is generally perceived as serving the particularistic interest of one group, it starts losing its legitimacy and indeed, its authority... 
Being deliberately partisan with state sensitive issues bordering on religion, ethno-religious wanton killings, unprovoked destruction of properties, inflicting serious physical injuries to defenseless and harmless law abiding citizens have grievous implications for security and nation building. The security challenges being faced by Nigerians today is an offshoot of government actions and inactions on issues of national interests, that required responsive and unbiased action to protect, sustain and nurture the unity of Nigeria.

\section{National Integration and Nation Building}

The contentious issue in the indigene/settler controversy is the claim of long-time settlement of non-indigenes in a particular state of their current abode as their original ancestral home by extension of their immense socio-economic and cultural contributions to the development of the area in question. What constitutes indigenes of a state is explicitly expressed in Section 8, Sub-section 1 (a)-(b) of the Constitution of the Federal Republic of Nigeria. Residing in a particular state in Nigeria for one hundred years or more, other than one's own state of origin does not make one an indigene of that state. Rather, free movement of people, goods and services encourages national integration of all people irrespective of state of origin, religion, or circumstances surrounding one's birth. Accordingly, Section 15, Sub-section 2 of 1999 Constitution of the Federation provides that "national integration shall be actively encouraged, whilst discrimination on the ground of place of origin, sex, religion, status, ethnic or linguistic association or ties shall be prohibited". This provision does not warrant any tribe living in any State of the federation to struggle Indigeneship status with its aborigines to contest for all the rights and privileges appertaining to the natives.

The Constitution is elaborately eloquent enough to guide on issues pertaining to national integration. For example, Section 15(3)(a)-(b) stipulates that "for the purpose of promoting national integration, it shall be the duty of the State to provide adequate facilities for and encourage free mobility of people, goods and services throughout the Federation; and secure full residence rights for every citizen in all parts of the Federation". Also Section 15(4) provides that "the State shall foster a feeling of belonging and of involvement among the various peoples of the Federation, to the end that loyalty to the nation shall override section loyalties". There is no provision for non-indigenes to tussle for Indigeneship rights and privileges with the host communities. The emphasis on this sub-section, by implication, centres on harmonious coexistence of Nigerian citizens, religious tolerance, creation of sense of belonging, and sustenance of the national slogan "one nation, one people, one destiny" to foster the motto of the Federal Republic of Nigeria in Section 15(1) of 1999 Constitution, which stipulates "Unity and Faith, Peace and Progress". Section 14(3) of the Constitution is emphatic on "the composition of the Government of the Federation or any of its agencies and the conduct of its affairs shall be carried out in such a manner as to reflect the federal character of Nigeria and the need to promote national unity, and also to command national loyalty, thereby ensuring that there shall be no predominance of persons from a few States or from a few ethnic or other sectional groups in that Government or in any of its agencies". This provision is one of the major reasons why minority ethnic indigenes are 'fighting' against predominant influence of non-indigenes in their host communities, who most often attempt to usurp the political or traditional positions federal character policy or cultural norm allotted to the indigenes as a people. Appointment of a non-indigene to represent the indigenes hosting him is fraud, a denial of fundamental right of the indigenous people and incisive action against Unity and Faith, Peace and Progress of the country.

\section{Conclusion}

A nation that laid its foundation on sentiments of ethnic nationalities, primordial political ideologies and insensitivity on matters of national interest is bound to disintegrate due to mistrust, suspicion, fear of domination, and political marginalization. The attitude of fanning indigenes and settlers bloody conflicts to gain cheap political popularity amongst a people is the least character expected from a patriotic statesman. The indigene/settler intractable crisis is nurtured and sustained by government at all levels. Whittling down or trivializing reports and recommendations from various panels of inquiries statutorily constituted is unfortunate. Non-intervention of government in the conflicts of the Fulani herdsmen and farmers all over Nigeria, non-provision of grazing land for cattle rearing, patting the back of Fulani's at the end of each clash with any group are actions that suggest government partisan, laissez-faire approach to sensitive issues of urgent national interest are some of the patterns of weak regime responses. The persistence of bloody clashes is caused more by the weak responses of the successive regimes rather than the communities themselves. The resolution of the ethnoreligious conflicts, indigenes/settlers feuds, and Hausa/Fulani herdsmen and farmers crisis have been made much more difficult by either apathy, or partisan responses of the successive administrations. Government should take decisive actions to curb the excesses of any tribe/s in our effort to foster peace and unity, security and national growth. The study 
revealed that lopsided redistribution of society benefits and the unhealthy struggle for scarce economic resources, cultural heritage syndrome and distrust are the main causes of indigenous claim and settlers discrimination. The study also revealed that those sponsoring these evil acts and the culprits are not prosecuted to face the wrath of the law. The indigenes and settlers question, Hausa/Fulani herdsmen unguarded incursions into autonomous communities' farming zones to graze their cattle, federal and state governments' weak and partisan response, apparently whittles down the seriousness of the ugly menace and by extension weakens governments' impetus to take decisive actions on related cases. Notwithstanding these obvious facts, there is need for the entire citizenry to positively unite and harness our differences in religion, diversity in culture, linguistic, varying history of a heterogeneously constituted black populous nation, to build a virile state full of potentialities.

\section{Reference}

Adetula, V.A.O. and Dung, Pam Sha (2006). "Sectarian Conflicts in Nigeria and their Implications for Electoral Violence". Paper Prepared for IFFS Seminar on Preventing Electoral Violence in Nigeria: June 27-28, Sheraton Hotel and Towers, Abuja.

Adetutu, A. (2012). "Nigerians Constitution must Resolve Indigene-Settler Issue". [Online] Available: http://thenationalineng.net/new/nigerian-constitution-must-resolve-indigene-settler-issue (22/02/2014)

Akpuru-Aja, A. (2007). Basic Concepts, Issues and Strategies of Peace and Conflict Resolution. Enugu: Keny and Brothers Ent. (Nig.).

Albert, O. I. (2004). "Ife-Modakeke Crisis" in Onigu Otite, Olawale I. Albert (eds.) Community Conflict in Nigeria: Management, Resolution and Transformation. Ibadan: Spectrum Books Limited.

Amaza, M. (2012). "Bridging the Indigene-Settler Divide". [Online] Available: http://nigerianstalk.org.2012/12/20//bridging-the-indigenesettler-divide (20/02/14)

Best, S.G. (2006). The Methods of Conflict Resolution and Transformation. In S. G. Best (ed.) Introduction to Peace and Conflict Studies in West Africa: A Reader. Ibadan: Spectrum Books Ltd.

Campbell, J. (2012). Rethinking Nigeria's Indigene-Settler Conflicts. Retrieved from Blogs.cfr.org/Campbell/2012/rethinking-nigeriansindigene-settler-conflicts (14/06/2014).

CJN Refuses to Swear in Appeal Court Justice. [Online] Available: http://agora.nigeriagovernance.org/2012/11/cjn-refuses-toswear-in-appeal-court-justice/ (11/1/2016)

Definition of Indigenous Peoples. [Online] Available: http://indigenouspeoples.nl/indigenous-peoples/definition-Indigenous $(5 / 1 / 2016)$

Egwu, S. et al (2003). "Communal Conflict and Population Displacement in Zango-Kataf" in Okwudiba Nnoli (ed.) Communal Conflict and Population Displacement in Nigeria: A Research Report. PACREP Book Series, No.1.

Ehusani, G. (2005). Citizenship and the Indigene/Settler Syndrome. [Online] Available: http://www.dawodu.com/ehusani2.htm $(07 / 04 / 2014)$.

Falola, T. and Heaton, M. (2008). A History of Nigeria. New York: Cambridge University Press.

Fatile, J. O. and Awotokun, K. (2009). "Ife-Modakeke Crisis" in M. Ikejiani-Clark (ed.) Peace Studies and Conflict Resolution in Nigeria: A Reader. Ibadan: Spectrum Books Ltd

Federal Republic of Nigeria (1999). Constitution of the Federal Republic of Nigeria (Promulgation) Decree 1999, No.24. Lagos: Government Press.

Ibrahim, J. (1999). "Ethno-Religious Mobilization and Sapping of Democracy in Nigeria" in J. Hyslop (ed.) African Democracy in the Age of Globalization. Witwaterand University Press.

Jones, M. (2012). "Playing the Indigenous Card? The Shetland and Orkney Udal Law Group and Indigenous Rights". GeoJournal, 77(6): 765 - 775. [Online] Available: http://link.springer.com/article/10.1007\%2Fs10708-010-9380-8 (12/1/2016). Indigenous Peoples. [Online] Available: $h$ ttp://en.wikipedia.org/wiki/indigenous_peoples (05/01/2016).

Otite, O. and Albert, O. (1999). Community Conflicts in Nigeria: Management, Resolution and Transformation. Ibadan: Spectrum Books for Academic Peace-works Associates.

Osaghae, E. and Suberu, R. (2005). A History of Identities, Violence and Stability in Nigeria. Centre for Research on Inequality, Human Security and Ethnicity, CRISE Working Paper, No. 6 January.

Ostien, P. (2009). "Jonah Jang and Jasawa: Ethno-Religious Conflict in Jos, Nigeria". [Online] Available: http://www.sharia-in-africa.net (25/03/2014).

"Partnering with Indigenous Peoples to Defend their Lands, Languages, and Cultures: Aboriginal Australians: The State of Play". [Online] Available: $h$ ttp//www.culturalsurvival.org/Australia?gclid=CJ357e3LhLoCFRKe4AodgAUA_A (30/4/14).

Sampson, J. M. (n.d). "The Perspectives and Causes of Conflicts in Jos". [Online] Available: http://www.nairaland.com/998903/perspectives-causes-conflicts-jos (13/03/2014).

Smyth, M. and Robinson, G. (2001). Researching Violently Divided Societies: Ethical and Methodological Issues. Tokyo: United Nations University Press. 